\title{
TEKNOLOGI PORTABLE INFLATED GREENHOUSE SEBAGAI FASILITAS PENDUKUNG PENINGKATAN KETAHANAN PANGAN DAN PERTANIAN PERKOTAAN (URBAN FARMING)
}

\author{
Ronny Durrotun Nasihien, Diah Ayu Restuti Wulandari, Achfas Zacoeb, \\ Harimurti, Ikhsan Setiawan \\ Universitas Narotama Surabaya \\ Email: ikhsan.setiawan@ narotama.ac.id
}

\begin{abstract}
Agricultural Urban (Urban Farming) utilizing land intensification, in order to meet the needs of the fresh fruit and vegetables daily for the public residential/housing in urban areas. Portable Technology Greenhouse inflated as urban agriculture production support facilities, can be built and transferred to a residential location / specific housing is easy, safe, fast and lightweight (PVC $0,55 \mathrm{~mm}$ Tarpaulin) so that urban agricultural products closer to consumers in urban settlements, the impact price getting cheaper, but quality. The long term goal is to develop protitipe Portable inflated Greenhouse as facilities Urban Farming which fulfills the power, speed, effectiveness, comfort and encourage crops of fruit / vegetable hydroponic hygienic, cheap and profitable, so that the product Portable inflated Greenhouse automatically support an increase in food production of the National, Specific target is the availability protitipe Portable Greenhouse inflated as Urban Farming facility in order to increase productivity of crops of fruit/vegetable hydroponic hygienic, cheap and profitable, so the high prospects for mass production in order to meet national food requirements. Methods using methods Experiments and Action Research, starting with the development of the design, manufacture, testing and repair of prototype Portable inflated Greenhouse includes (1) a test of strength and endurance of materials Portable inflated Greenhouse to weather, (2) test material Portable inflated Greenhouse most effective as a component of the structure, (3) test the speed of manufacture, transport, assembly, installation, dismantling Portable inflated Greenhouse, (4) the test temperature, humidity and air pressure within the Portable inflated Greenhouse, (5) test crops of fruit/vegetables hydroponically are suitable to be developed in inflated portable building a greenhouse in order to obtain yields hygienic, inexpensive andprofitable.The first year developing a prototype design Portable Greenhouse inflated, followed prototyping and ends with prototype testing and field trials at The Lab Narotama, published in the SeminarS/Proceeding International and International Journals indexed, filed a registration PATENT Kemenkumham.The results this research were published in the Appropriate Technology Seminar/Proceeding International and International Journals indexed, processed PATENT Kemenkumham, and is eligible to be mass produced to support the acceleration of National hygienic food production, cheap and profitable.
\end{abstract}

Keywords: Portable Inflated Greenhouse, Urban Farming, Greenhouse 


\begin{abstract}
Abstrak
Pertanian Perkotaan (Urban Farming) memanfaatkan intensifikasi lahan, guna memenuhi kebutuhan sayuran dan buah segar sehari-hari bagi masyarakat pemukiman/perumahan di perkotaan. Teknologi Portable inflated Greenhouse sebagai fasilitas pendukung produksi pertanian perkotaan, dapat dibangun serta dipindahkan ke lokasi pemukiman/perumahan tertentu secara mudah, aman, cepat dan ringan (0,55mm PVC Terpaulin) sehingga produk pertanian perkotaan semakin dekat dengan konsumen pemukiman di perkotaan, dampaknya harga semakin murah namun berkualitas. Tujuan jangka panjang adalah mengembangkan protitipe Portable inflated Greenhouse sebagai fasilitas Urban Farming yang memenuhi aspek kekuatan, kecepatan, efektifitas, kenyamanan serta mendorong hasil panen tanaman buah/sayuran hidroponik yang higienis, murah dan menguntungkan, sehingga produk Portable inflated Greenhouse otomatis mendukung peningkatan produksi pangan Nasional. Target khusus adalah tersedianya protitipe Portable inflated Greenhouse sebagai fasilitas Urban Farming guna peningkatan produktifitas tanaman buah/sayuran hidroponik higienis, murah dan menguntungkan, sehingga berprospek tinggi untuk diproduksi massal guna memenuhi kebutuhan pangan Nasional. Metode Penelitian menggunakan Metode Eksperimen dan Action Research, diawali dengan pengembangan rancang bangun, pembuatan, pengujian dan perbaikan prototipe Portable inflated Greenhouse meliputi (1) uji kekuatan dan ketahanan bahan Portable inflated Greenhouse terhadap cuaca, (2) uji bahan Portable inflated Greenhouse yang paling efektif sebagai komponen struktur, (3) uji kecepatan pembuatan, pengangkutan, perakitan, pemasangan, pembongkaran Portable inflated Greenhouse, (4) uji temperatur, kelembaban dan tekanan udara didalam Portable inflated Greenhouse, (5) uji tanaman buah/sayuran hidroponik yang cocok dikembangkan dalam bangunan portable inflated greenhouse sehingga diperoleh hasil panen yang higienis, murah dan menguntungkan. Tahun pertama melakukan pengembangan rancang bangun prototipe Portable inflated Greenhouse, dilanjutkan pembuatan prototipe dan diakhiri dengan uji coba prototipe serta uji coba lapangan di di Lab Universitas Narotama, dipublikasikan pada Seminar/Proceeding Internasional dan Jurnal Internasional terindex, diajukan registrasi PATEN KemenkumHAM. Hasil penelitian berupa Teknologi Tepat Guna dipublikasikan pada Seminar/Proceeding Internasional dan Jurnal Internasional terindex, diproses PATEN KemenkumHAM, serta layak diproduksi massal guna mendukung percepatan produksi pangan Nasional yang higienis, murah dan menguntungkan.
\end{abstract}

Kata Kunci : Portable inflated Greenhouse, Urban Farming, Greenhouse

\title{
A. Latar Belakang
}

FAO (Food and Agriculture Organization) menjelaskan Pertanian Perkotaan sebagai industri yang memproduksi, memproses, dan memasarkan produk pertanian, terutama memenuhi permintaan harian konsumen di dalam 
perkotaan, dengan metode produksi intensif, memanfaatkan dan mendaur ulang sumber daya dan limbah perkotaan untuk menghasilkan beragam tanaman kebutuhan pangan masyarakat Perkotaan (Smit, J, A. Ratta, J. Nasr, 1996). Council on Agriculture, Science and Technology (CAST) menyatakan Pertanian Perkotaan mencakup aspek kesehatan lingkungan, remediasi, dan rekreasi (Butler, L, Moronek, D.M, 2002). Di berbagai kota, Pertanian Perkotaan menjadi pendukung aspek keindahan kota dan kelayakan penggunaan tata ruang yang berkelanjutan. Pertanian Perkotaan juga dilakukan untuk meningkatkan pendapatan atau aktivitas memproduksi bahan pangan untuk dikonsumsi keluarga, dan di beberapa tempat dilakukan untuk tujuan rekreasi dan relaksasi (Fraser, Evan D.G, 2002). Di USA pertanian kota mempunyai peranan dalam pengurangan kemiskinan, kerawanan pangan dan mengatasi permasalahan sampah.

Pertanian kota dapat menjamin ketersediaan pangan yang segar dan bergizi, sehingga meningkan asupan sayuran dan buah dan dapat menghemat pengeluaran 15-30 persen anggaran pada pangan (kabarkampus.com). Potensi urban farming di Indonesia sangat besar, dari 10,3 juta ha lahan pekarangan yang belum dimanfaatkan lebih dari $30 \%$ berada di perkotaan. Selain itu konsumsi sayur dan buah masyarakat Indonesia hanya sebesar $40 \mathrm{~kg} / \mathrm{kapita} / \mathrm{tahun}$, sementara Food and Agriculture Organization of the United Nations (FAO) mensyaratkan konsumsi sayur idealnya sebesar $73 \quad \mathrm{~kg} \quad \mathrm{~kg} / \mathrm{kapita} / \mathrm{tahun}$ (industri.bisnis.com). Pertanian Perkotaan memberikan hasil yang optimal dengan fasilitas Greenhouse dan teknologi Hidroponik. Greenhouse meningkatkan perlindungan tanaman dari intensitas hujan, sinar matahari dan iklim mikro, serta mengoptimalkan pemeliharaan tanaman, pemupukan dan irigasi mikro, sehingga mampu meningkatkan produksi sayuran, buah dan bunga yang berkualitas tanpa tergantung dengan musim (G. Thiyagarajan, R. Umadevi \& K. Ramesh, 2007). Greenhouse semakin mudah dengan teknologi Portable inflated Structure yang dapat memenuhi syarat kekuatan, kenyamanan dalam ruang dan kecepatan dalam pembangunan Greenhouse tersebut. Bahan membran Portable inflated Structure dapattahan terhadap cuaca hingga lebih dari 10 tahun, bergantung kepada jenis bahan coatingnya (Setiawan, M. Ikhsan \& Nasihien, Ronny D, 2014). Selain itu Bahan membran Portable inflated Structure terbukti handal berdasarkan 
pengujian di Lab Universitas Narotama serta Uji Lapangan, memberikan hasil yang memuaskan meliputi kuat uji tarik hingga $218,3 \mathrm{~kg}$, daya tahan material $>70^{\circ} \mathrm{C}$, instalasi 3menit, pemasangan 3 menit dan pembongkaran 3 menit serta suhu dalam ruangan $<35^{\circ} \mathrm{C}$ (Setiawan, M. Ikhsan \& Nasihien, Ronny D, 2015). Portable inflated Structure dapat digunakan pada area terbatas, bahan struktur ringan $(0.55 \mathrm{~mm}$ PVC Terpaulin), mudah dipindah, dilipat maupun diangkut ke lokasi lain hanya dengan truk/pickup

\section{B. Perumusan Masalah}

Terdapat 5 (lima) aspek utama yang menjadi masalah dalam Penelitian Kerjasama antar Perguruan Tinggi (Pekerti), yaitu:

1. Pengembangan desain portable inflated greenhouse.

2. Pengembangan prototipe portable inflated greenhouse dilanjutkan uji material bangunan

3. Kecepatan dan efektivitas dalam proses pengangkutan, perakitan, pemasangan serta pembongkaran bangunan portable inflated greenhouse.

4. Tingkat kenyamanan termal (temperatur, kelembaban dan tekanan udara) dalam bangunan portable inflated greenhouse guna pertumbuhan tanaman buah/sayuran

Berdasarkan latar belakang dan identifikasi masalah, maka dapat dirumuskan permasalah Penelitian Kerjasama antar Perguruan Tinggi (Pekerti) sebagai berikut:

1. Bagaimana pengembangan desain portable inflated greenhouse?

2. Bagaimana pengembangan prototipe portable inflated greenhouse dilanjutkan uji material bangunan?

3. Bagaimana kecepatan dan efektivitas dalam proses Pengangkutan, perakitan, pemasangan serta pembongkaran bangunan portable inflated greenhouse?

4. Bagaimana tingkat kenyamanan termal (temperatur, kelembaban dan tekanan udara) dalam bangunan portable inflated greenhouse guna pertumbuhan tanaman buah/sayuran? 


\section{Urgensi (Keutamaan) Penelitian}

Urgensi (keutamaan) Penelitian Kerjasama antar Perguruan Tinggi (Pekerti) adalah sebagai berikut:

1. Potensi Pertanian Perkotaan (urban farming) di Indonesia sangat besar, dari 10,3 juta hektar lahan pekarangan yang belum dimanfaatkan lebih dari 30\% berada di perkotaan. Selain itu konsumsi sayur dan buah masyarakat Indonesia masih minim hanya sebesar $40 \mathrm{~kg} / \mathrm{kapita} / \mathrm{tahun}$, sementara Food and Agriculture Organization of the United Nations (FAO) mensyaratkan konsumsi sayur idealnya sebesar $73 \mathrm{~kg} \mathrm{~kg} / \mathrm{kapita} / \mathrm{tahun}$ (industri.bisnis.com)

2. Pertanian Perkotaan (urban farming) memberikan hasil yang optimal dengan fasilitas Greenhouse dan teknologi Hidroponik. Teknologi Greenhouse meningkatkan perlindungan tanaman dari intensitas hujan, sinar matahari dan iklim mikro, serta mengoptimalkan pemeliharaan tanaman, pemupukan dan irigasi mikro, sehingga mampu meningkatkan produksi sayuran, buah dan bunga yang berkualitas tanpa tergantung dengan musim (G. Thiyagarajan, R. Umadevi \& K. Ramesh, 2007).

3. Penelitian menunjukkan bahwa jika urban farming diterapkan pada perumahan/pemukiman di Surabaya, dapat menarik minat beli konsumen, potensial konsumen adalah keluarga muda perumahan kelas menengah ke atas, dan urban farming dominan diinginkan adalah tanaman buah (Ghana, Ayu Kemala, 2014)

4. Teknologi Greenhouse semakin mudah didukung penerapan teknologi Portable inflated Structure yang dapat memenuhi syarat kekuatan, kecepatan, kenyamanan dalam ruang dan kelayakan pertumbuhan tanaman buah/sayuran hidoponik didalamnya

5. Teknologi Portable inflated Greenhouse menjadi solusi ketersediaan pangan di perkotaan yang higienis, murah dan menguntungkan, disebabkan penempatan Greenhouse yang fleksibel di pemukiman/perumahan disertai teknologi hidroponik yang sudah umum diterapkan masyarakat pertanian perkotaan.

6. Teknologi Portable inflated Greenhouse memiliki prospek tinggi guna diproduksi massal oleh UMKM Mitra, disebabkan tingginya kebutuhan 
pangan perkotaan dan minimnya ketersediaan produksi pangan yang higienis namun murah harganya.

\section{Luaran Yang Akan Dicapai Setiap Tahunnya}

Luaran yang akan dicapai setiap tahunnya pada Penelitian Kerjasama antar Perguruan Tinggi (Pekerti) adalah sebagai berikut:

1. Tahun 2017, meliputi:

a. Prototipe Teknologi Tepat Guna Portable inflated Greenhouse teruji di Lab Universitas Narotama

b. Publikasi hasil penelitian dalam bentuk Seminar/Proceeding Internasional dan Jurnal Internasional terindex SCOPUS

c. Registrasi PATEN di KemenkumHAM

2. Tahun 2018, meliputi:

a. Perbaikan Prototipe dan uji lanjutan Teknologi Tepat Guna Portable inflated Greenhouse di Lab Universitas Narotama

b. Publikasi hasil penelitian dalam bentuk Seminar/Proceeding Internasional dan Jurnal Internasional terindex SCOPUS

c. Proses PATEN di Kemenkum HAM
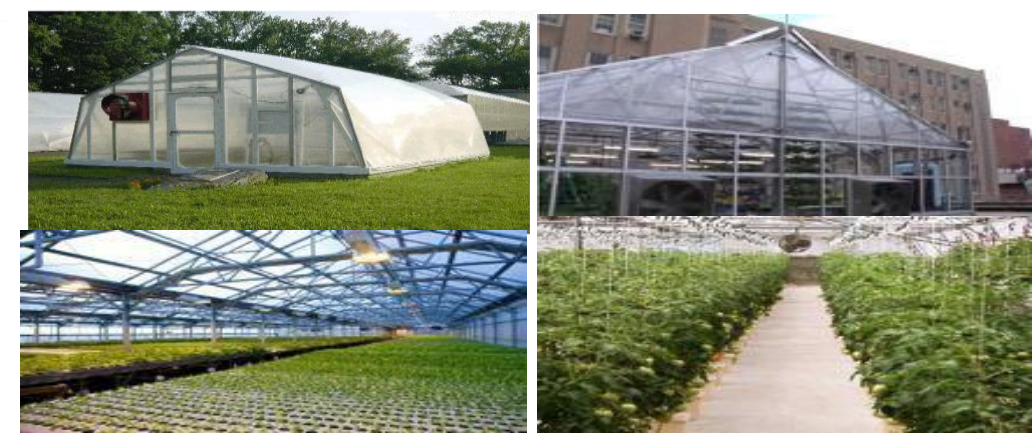

Gambar 1. Greenhouse dan alat pendukungnya Sumber: greenestcity.ca

\section{E. Tinjauan Pustaka}

\section{Teknologi Greenhouse Urban Farming}

Perumahan/pemukiman ramah lingkungan (green property) saat ini memiliki kecenderungan menjadi daya tarik bagi konsumen. Pengembang ditantang untuk memberikan unique selling point yang nyata dalam produk propertinya untuk menarik minat konsumen pada tren hijau ini. Pertanian kota 
(urban farming) memiliki potensi tidak hanya hijau tetapi juga produktif. Dengan konsep urban farming, konsumen tidak hanya mendapat manfaat hijaunya tetapi juga hunian yang terintegrasi dengan sarana refreshing dalam bentuk wisata pertanian. Peluang inilah yang dapat dijadikan bisnis pengembang sebagai diversifikasi dari konsep green property ditengah persaingan properti hunian. Sedangkan potensi bagi pengembang di Surabaya adalah belum ada perumahan yang mengusung konsep urban farming (Ghana, Ayu Kemala, 2014). Selain itu Pertanian Perkotaan memunculkan komunitas seperti "foodies", "locavores", "organic growers" yang berfungsi sebagai sarana berbagi informasi dan fasilitas jual beli produk setempat, sehingga mendatangkan penghasilan, mengurangi risiko pestisida dan bahan kimia berlebih dalam konsumsi masyarakat, sehingga meningkatkan ketahanan pangan, karena mendekatkan jarak antara produsen dan konsumen sehingga bahan pengawet dan proses tambahan tidak dibutuhkan. Hal ini membuat konsumen mendapatkan jaminan bahan pangan yang didapatkan begitu segar (Thornton, A, 2011).

Studi memperlihatkan bahwa dengan berpindah dari bahan pangan yang ditumbuhkan secara lokal dapat menghemat emisi dari transportasi bahan makanan sebanyak 50.000 metrik ton karbon dioksida, yang setara dengan menghilangkan 16.191 mobil dari jalan. Sebagai dampak berkurangnya penggunaan energi, jejak karbon dari suatu kota akibat usaha Pertanian Perkotaan juga berkurang. (Xuereb, M, 2005), (Delta Institute, 2013). Belanda salah satu negara dengan penerapan teknologi hidroponik paling maju. Negeri Kincir Angin itu merupakan negara produsen produk hidroponik terbesar di dunia. Total luas lahan budidaya secara hidroponik mencapai 10.000 ha. Produk hidroponik di Belanda menyumbang 50\% dari nilai semua buah dan sayuran yang dihasilkan di negeri itu. Komoditas utama yakni paprika, tomat, dan mentimun serta bunga potong terutama mawar, gerbera, carnation, dan chrysanthemum. Sebagian besar pasar ditujukan untuk ekspor. Hampir semua kegiatan produksi di dalam rumahkaca menggunakan teknik hidroponik dengan sistem NFT dan kultur rockwool. NFT adalah suatu metode budidaya tanaman dengan akar tanaman yang tumbuh pada lapisan nutrisi yang dangkal dan tersirkulasi. Tanaman tumbuh dalam lapisan polyethylene dengan akar tanaman terendam dalam air yang berisi 
larutan nutrisi yang disirkulasi secara terus menerus dengan pompa. Dengan demikian tanaman dapat memperoleh cukup air, nutrisi dan oksigen. Sedangkan Rockwool atau biasa dikenal dengan Mineral Wool juga merupakan teknik hidroponik yang dibuat dengan memanaskan bebatuan mineral dalam suhu yang sangat tinggi sehingga menjadi serat-serat. Serat-serat ini kemudian dimasukkan dalam semacam alat pintal dan kemudian menjadi bentuk yang mirip dengan busa. Rockwool yang dipotong kecil berbentuk kubus selanjutnya ditempatkan dalam pot kecil berlubang (Net Pot) sehingga akar tanaman yang keluar dari Rockwool dapat terus berkembang dan terjuntai untuk bisa menyerap nutrisi dan oksigen yang terkandung dalam air dibawahnya (trubus-online.co.id).

Penelitian dan pengujian terhadap sistem struktur pneumatik, antara lain dalam uji model struktur pneumatik pada tahun 1992 telah dilakukan dalam paper "Kajian dan Perancangan Bangunan dengan Konsep Struktur Pneumatik yang Ditekankan pada Aspek Teknik dan Metoda Konstruksi, Kasus Studi: Struktur Atap Pneumatik Membran Tunggal yang Ditumpu Udara pada Gedung Olah Raga” (Budiyanto, Hery, 1992). Eksperimen model struktur diperlukan untuk mengetahui perilaku struktur sesungguhnya (prototipe) dengan menggunakan replika (model) struktur yang skalanya lebih kecil. Salah satu rekomendasi penelitian tersebut adalah struktur pneumatik memiliki beberapa kelebihan dibandingkan dengan struktur bangunan konvensional, yaitu investasi awal lebih murah, kecepatan dan kemudahan pembangunan, pemeliharaan mudah, elemen struktur dapat dilipat (ringkas) sehingga dapat disimpan dalam gudang dengan ukuran 3x3 m2. Eksperimen dilanjutkan dengan Penelitian Hibah Bersaing DIKTI Tahun 2008-2010 yang menghasilkan prototipe struktur pneumatik yang ditumpu oleh udara (Budiyanto, Hery, 2010). Prototipe ini dapat dibangun hanya dalam waktu 30 menit, bangunan seluas $150 \mathrm{~m} 2$ siap menampung 50 orang. Kelemahan dari prototipe ini adalah penggunaan pintu rigid yang harus kedap udara sehingga menyulitkan masyarakat awam untuk membiasakan diri keluar masuk dari tenda gelembung. Hasil riset Purwanto yang dituangkan dalam tulisan berjudul “Perkembangan Struktur Pneumatik Memperkaya Desain Arsitektur" (Purwanto, 2000) menyampaikan kemungkinan penerapan dan pengembangan struktur pneumatik di Indonesia, antara lain kondisi iklim di Indonesia, terutama masalah 
angin, bukanlah masalah yang berarti dan dapat diperhitungkan dengan perhitungan tekanan dalam struktur pneumatik.

Hal-hal yang perlu dipertimbangkan dalam penggunaan struktur pneumatik di Indonesia, antara lain perilaku, kondisi sosial masyarakat Indonesia perlu ditingkatkan terutama dalam pemeliharaan bangunan. Aspek keisengan masyarakat dalam memandang dan memperlakukan bangunan/fasilitas umum sering menimbulkan kerusakan. Namun, masyarakat perlu dibiasakan dan dikenalkan dengan sistem struktur baru ini sehingga dapat belajar pada satu kondisi, bentuk, perilaku atau peradaban baru. Alain Chassagnoux dan kawankawan dalam "Teaching of Morphology" (Chassagnoux et.al., 2002) menjelaskan bahwa untuk mempelajari bentuk-bentuk arsitektur kontemporer yang menggunakan struktur non-konvensional. Para dosen bisa mengajak mahasiswa untuk melakukan eksperimen model sehingga mendapatkan pengalaman "membentuk" bangunan menggunakan elemen/komponen yang dirancang sendiri oleh mahasiswa. Dengan studi bentuk bangunan melalui studi geometri dan sains akan memberikan pengalaman pembentukan struktur bangunan yang sulit dilakukan dan hiperhitungkan secara matematis. Teknologi Greenhouse semakin mudah dengan teknologi Portable inflated Structure yang dapat memenuhi syarat kekuatan, kenyamanan dalam ruang dan kecepatan dalam pembangunan Greenhouse tersebut. Bahan membran Portable inflated Structure dapat tahan terhadap cuaca hingga lebih dari 10 tahun, bergantung kepada jenis bahan coatingnya (Setiawan, M. Ikhsan \& Nasihien, Ronny D, 2014).

Selain itu Bahan membran Portable inflated Structure terbukti handal berdasarkan pengujian di Lab Universitas Narotama serta Uji Lapangan, memberikan hasil yang memuaskan meliputi kuat uji tarik hingga 218,3 kg, daya tahan material $>70^{\circ} \mathrm{C}$, instalasi 3menit, pemasangan 3menit dan pembongkaran 3 menit serta suhu dalam ruangan $<35^{\circ} \mathrm{C}$ (Setiawan, M. Ikhsan, Nasihien, Ronny D, et.al, 2015(a)). Portable inflated Structure dapat digunakan pada area terbatas, bahan struktur ringan $(0.55 \mathrm{~mm}$ PVC Terpaulin), mudah dipindah, dilipat maupun diangkut ke lokasi lain hanya dengan truk/pickup (Setiawan, M. Ikhsan, Nasihien, Ronny D, et.al, 2015(b)) 


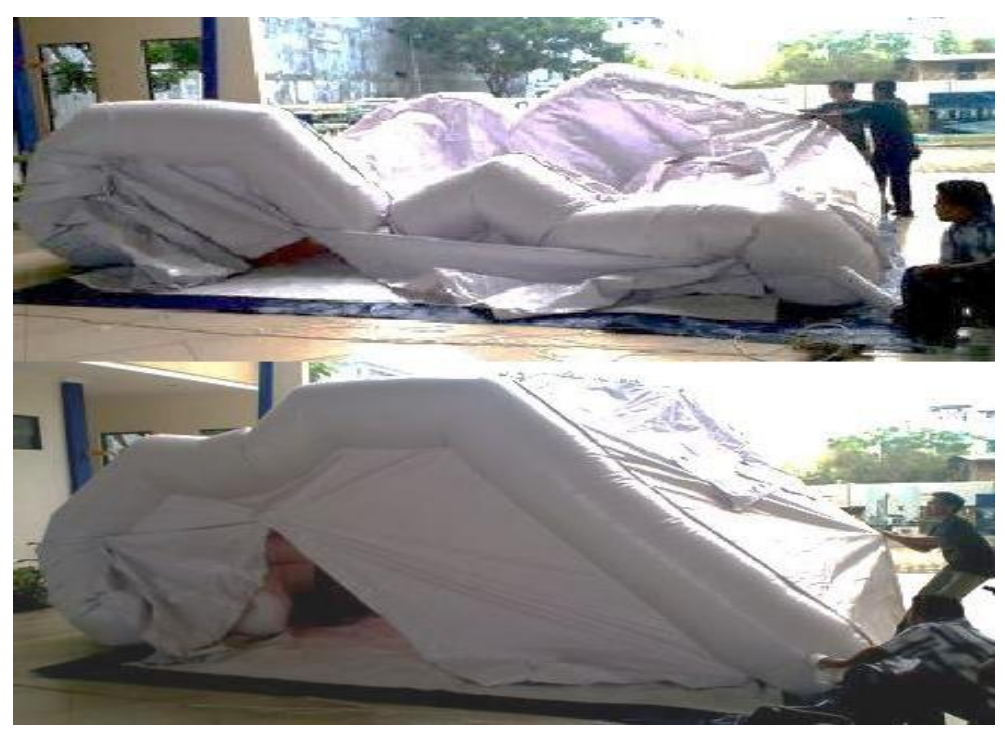

Gambar 2. Proses Setting-Up Portable inflated Structure

(Sumber : Setiawan, M. Ikhsan, Nasihien, Ronny D, et.al, 2015(a))
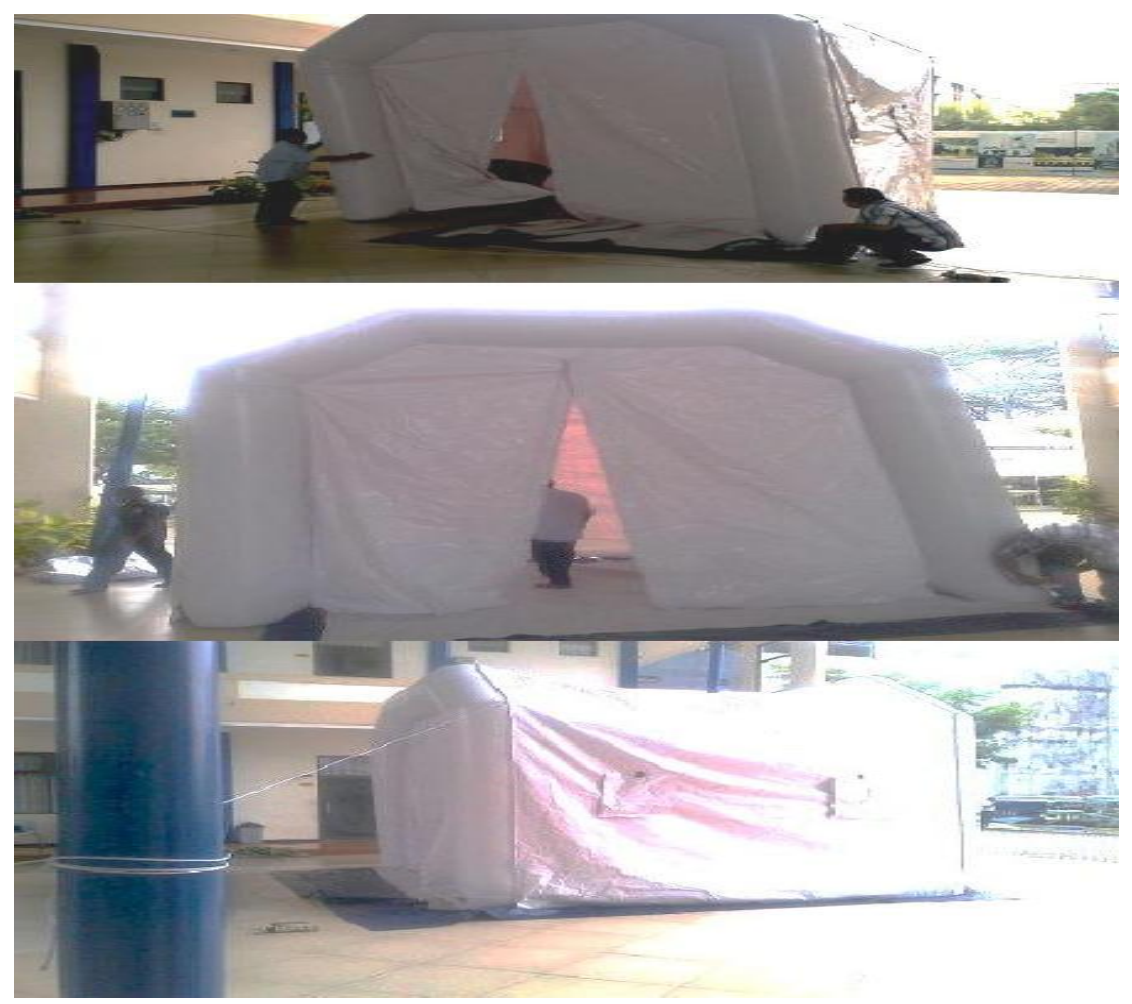

Gambar 3. Proses Finishing Portable inflated Structure

(Sumber : Setiawan, M. Ikhsan, Nasihien, Ronny D, et.al, 2015(a)) 


\section{Teknologi Vascular Arbuscular Mycorrhizae (VAM)}

Penggabungan antara pembentukan jaringan perakaran dalam tanah antara dua-tiga jenis tanaman dengan perakaran yang berbeda dan Vascular Arbuscular Mycorrhizae (VAM) yang spesifik bersimbiose dengan tanaman-tanaman tersebut. Jaringan perakaran tanaman yang terbentuk pada kedalaman yang berbeda akibat perbedaan kemampuan distribusi akar masing-masing jenis tanaman akan membentuk suatu bentuk cawan dalam tanah. Cawan perakaran ini juga akan didukung oleh jaringan hifa VAM yang akan menghubungkan antara satu titik pada bagian akar tanaman dengan titik pada bagian tanah yang lebih dalam dan titik pada bagian akar yang lain, sehingga terbentuknya jaringan hifa VAM ini akan memperkokoh daya sangga dan daya pegang terhadap nutrisi, air, mineral, maupun mikroba lain yang terstimulir dan terserap ke rhizosfer akibat aktifitas VAM itu sendiri. Jadi, keberadaan VAM+tanaman inang akan memberikan keuntungan dalam beberapa hal:

1) Menyerap nutrisi lebih kuat dan lebih cepat dari dalam tanah serta mempertahankan keberadaan nutrisi tersebut melalui kemampuan menyangga dan kemampuan pegang yang lebih baik. Sangat efektif diterapkan pada tanah yang memiliki kemampuan pegang nutrisi lemah, seperti tanah bekas pertambangan timah, tanah berpasir di daerah pantai, maupun tanah lainnya dengan kemampuan kapasitas tukar kation (KTK) yang rendah.

2) Meningkatkan sifat supressifitas wilayah rhizosfer. Selain secara langsung keberadaan VAM akan dapat melindungi akar dari serangan pathogen dan hama tanah karena hifa VAM yang menyelimuti akar tanaman akan melindungi secara langsung dari infeksi pathogen, distribusi hifa dalam seluruh wilayah rhizosfer akan membentuk system baru yang berfungsi menyerap hara makro-mikro dalam tanah dan selanjutnya mengundang mikroba tanah untuk mendatangi wilayah rhizosfer. Mikroba tanah yang terundang akibat keberadaan system VAM+perakaran tanaman adalah terdiri dari sekitar 98 persen mikroba bermanfaat (decomposer, antagonis, patogen serangga, dls.) dan hanya sekitar 2 persen saja yang berperan sebagai pathogen tanaman. Keberadaan mikroba bermanfaat inilah yang meningkatkan sifat supressifitas tanah. 
3) Memperbaiki struktur tanah lebih cepat. Bangunan dalam tanah yang terbentuk dari system sebaran hifa VAM, komunitas mikroba baru, system perakaran tanaman dan bank nutrisi akan lebih cepat memperbaiki struktur tanah yang terganggu akibat aktifitas pertanian yang salah maupun akibat aktifitas pertambangan. Tanah bekas pertambangan timah yang berubah menjadi didominasi pasir (70-95\% dan bahkan bisa 100\%), akan dapat meningkat kualitasnya lebih cepat hingga 30 kali dengan penerapan system yang benar.

4) Terundangnya mikroba spesifik dari wilayah tertentu dalam kedalaman tanah tertentu. Mikroba spesifik ini tidak dapat terstimulasi selain dari rangsangan akibat adanya system SDN dimana terjadi gabungan antara stimulasi fisik, kimiawi dan biologi secara bersamaan.

5) Menguntungkan bagi petani karena memberikan keuntungan secara ekonomi berupa reduksi input pupuk kimiawi maupun non kimiawi dan pestisida. Sistem jaringan hifa yang terbentuk akan meningkatkan kemampuan akar dalam menyerap hara tanah hingga puluhan dan bahkan ribuan kali lipat. Kemampuan ini akan menurunkan kebutuhan nutrisi tanaman dari input pupuk dan pestisida.
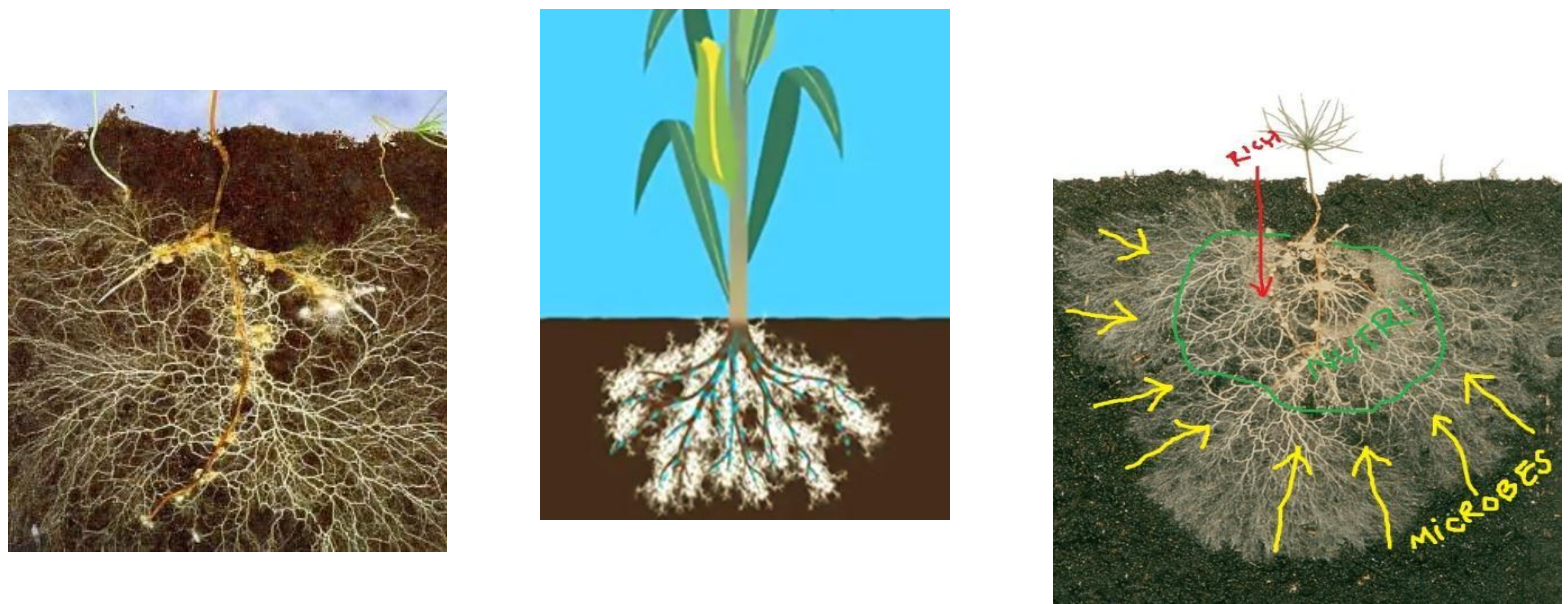

Gambar 4. Jenis tanaman yang berbeda membentuk distribusi perakaran yang berbeda. (Ki-ka: distribusi tiga jenis tanaman yang berbeda membentuk system perakaran baru; Infeksi VAM memperluas distribusi dan daya jangkau akar tanaman; Aktifitas akar+VAM meningkatkan serapan hara dan memeprkuat daya simpan hara, air, mineral dan mikroba

(sumber: Anton Muhibuddin, 2017) 


\section{F. Tujuan Dan Maksud Penelitian}

Tujuan Penelitian Kerjasama antar Perguruan Tinggi (Pekerti) adalah sebagai berikut:

1. Mengembangkan prototipe portable inflated greenhouse dilanjutkan uji material di Lab Universitas Narotama

2. Melakukan pengujian terkait fleksibilitas, kecepatan dan efektifitas dalam proses pembangunan portable inflated greenhouse di Lab Universitas Narotama serta di Workshop Mitra

3. Melakukan pengujian terkait kenyamanan termal (temperatur, kelembaban dan tekanan udara) dalam bangunan portable inflated greenhouse guna pertumbuhan tanaman buah/sayuran di Lab Universitas Narotama serta di Workshop Mitra UMKM

4. Melakukan pengembangan tanaman buah/sayuran dengan teknologi VAM, yang cocok dikembangkan dalam bangunan portable inflated greenhouse sehingga diperoleh hasil panen yang higienis, murah dan menguntungkan di Lab Universitas Narotama

5. Melakukan publikasi terkait hasil penelitian dalam bentuk Seminar/Proceeding Nasional, Jurnal Internasional terindex SCOPUS serta proses PATEN di KemenkumHAM

Manfaat khusus Penelitian Kerjasama antar Perguruan Tinggi (Pekerti) adalah sebagai berikut:

1. Tersedianya prototipe bangunan portable inflated greenhouse tanaman buah/sayuran Teknologi VAM yang memiliki kecepatan/efektivitas dalam proses pengangkutan, perakitan, pemasangan, pembongkaran, serta teruji kenyamanan termal (temperatur, kelembaban dan tekanan udara)

2 Tersedianya prototipe bangunan portable inflated greenhouse tanaman buah/sayuran Teknologi VAM yang membantu pertumbuhan tanaman buah/sayuran dengan baik

3. Tersedianya prototipe bangunan portable inflated greenhouse tanaman buah/sayuran Teknologi VAM yang dapat diproduksi massal sehingga dapat membantu percepatan produksi pangan Nasional yang higienis, murah dan menguntungkan 
4. Tersedianya publikasi terkait hasil penelitian prototipe portable inflated greenhouse tanaman buah/sayuran Teknologi VAM dalam bentuk Seminar/Proceeding Internasional, Jurnal Internasional terindex

5. Tersedianyan PATEN di KemenkumHAM terkait produk penelitian prototipe bangunan portable inflated greenhouse tanaman buah/sayuran Teknologi VAM

\section{G. Metode Penelitian}

Penelitian ini menggunakan metode eksperimental dan action research berupa pembuatan prototipe, melakukan uji coba Laboratorium dan uji coba Lapangan terhadap berbagai variabel (Cowan, 1968), berupa pengujian bahan membran portable inflated greenhouse terhadap: (1) kondisi cuaca; (2) fleksibilitas, kecepatan dan efektifitas; (3) kenyamanan termal dalam bangunan; (4) tanaman buah/sayuran Teknologi VAM yang cocok dikembangkan dalam bangunan sehingga diperoleh hasil panen yang higienis, murah dan menguntungkan. Pelaksanaan penelitian ini selama 2(Dua) Tahun mulai tahun 2017-2018, dengan Uji Lab dilakukan di Universitas Narotama. Proses pengembangan desain, perbaikan desain prototipe, uji teknis serta uji lanjutan produk Teknologi portable inflated greenhouse dilakukan di Lab Universitas Narotama.

Gambar 4. Alur Penelitian

Tujuan jangka panjang:
Mengembangkan
protitipe Portable
Inflated Greenhouse
sebagai fasilitas Urban
Farming teruji kekuatan,
kecepatan, efektifitas,
kenyamanan sehingga
mendorong pangan
buah/sayuran yang
higienis, murah \&
menguntungkan,
sehingga mendukung
peningkatan produksi
pangan Nasional.
Target khusus:
Tersedianya prototipe
Portable Inflated
Greenhouse sebagai
fasilitas Urban Farming
guna peningkatan
produktifitas tanaman
buah/sayuran hidroponik
higienis, murah \&
menguntungkan,
sehingga berprospek
tinggi diproduksi massal
Mitra UMkM
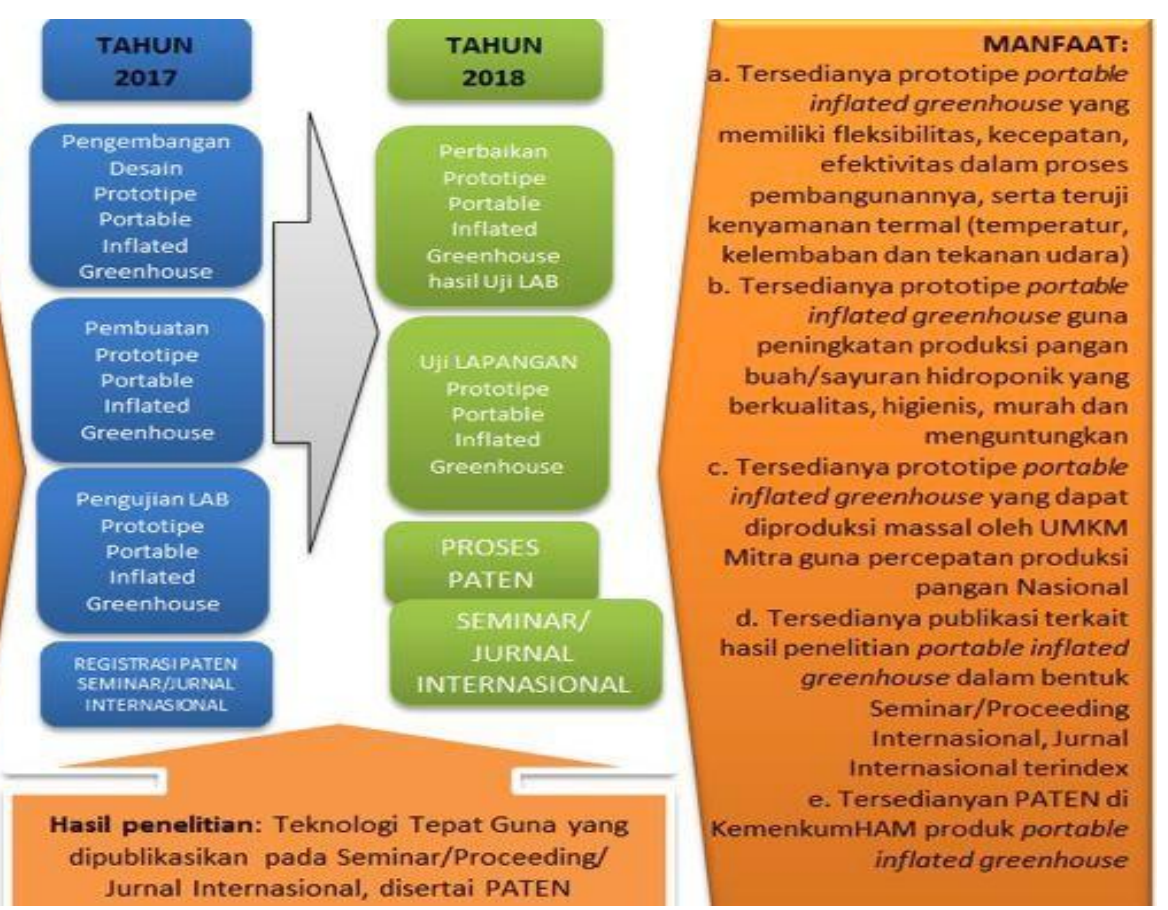


\section{TAHUN PERTAMA (I):}

1) Uji LAB Prototipe Portable Inflated Greenhouse Tanaman Buah/Sayur dengan teknologi VAM, melalui kegiatan: (a) Uji Coba di LAB Universitas Narotama, meliputi: (1) Uji fleksibilitas, kecepatan, efektifitas produk Prototipe Portable Inflated Greenhouse; (2) Uji daya tahan tanaman buah/sayuran dengan teknologi VAM dalam Prototipe; (b) Uji Coba Daya Tahan Tanaman Buah/Sayur dengan teknologi VAM. Kemudian dilanjutkan dengan Metode dan Teknik Analisis berupa analisis Kuantitatif (menggunakan Termometer, Stopwatch). Hasil akhir diperoleh Produk Prototipe Portable Inflated Greenhouse dengan Tanaman Buah/Sayur dengan teknologi VAM, yang telah di Uji Coba di LAB dan telah dilakukan revisi produk atas hasil Uji Coba di LAB Universitas Narotama tersebut.

2) Pelaksanaan PUBLIKASI, melalui kegiatan: (a) Persiapan dokumen untuk Publikasi Seminar/Proceeding Internasional dan Jurnal Internasional terindex SCOPUS. Selanjutnya dilakukan Metode dan Teknik Publikasi, meliputi:

a) Pengambilan/Pengolahan/Analisis data; dan

b) Pendaftaran, Registrasi, Editing, Translating, Abstract, Draft Full Paper, Final Full Paper, Reviewer Consultation, Sending Paper, Publishing. Kemudian dilanjutkan dengan Metode serta Teknik Analisis, berupa analisis Kualitatif (PUBLICATION). Hasil akhir diperoleh PUBLIKASI SEMINAR INTERNASIONAL dan DRAFT PUBLIKASI JURNAL TERINDEX SCOPUS atas produk Prototipe Portable Inflated Greenhouse

3) Pelaksanaan Registrasi PATEN, melalui kegiatan: (a) Identifikasi produk PATEN; (b) Persiapan dokumen PATEN; (c) Koordinasi dengan KEMENKUMHAM; (d) Pengajuan PATEN. Selanjutnya Teknik Registrasi PATEN, meliputi: (a) Pengambilan data PATEN; (b) Pengolahan data PATEN; (c) Penyerahan data PATEN. Kemudian dilanjutkan dengan Teknik Analisis pelaksanaan registrasi PATEN secara Kualitatif (Administrasi PATEN). Hasil akhir yang diperoleh adalah Registrasi PATEN atas produk Prototipe Portable Inflated Greenhouse 


\section{H. Hasil Dan Luaran Yang Dicapai}

\section{Presenter Dan Publikasi Bereputasi (Scopus Indexed)}

- International Conference ISKA17 di Johor, Malaysia (INTERNATIONAL CONFERENCE ON ENGINEERING APPLICATION, PHYSICS AND SCIENCES - ICEAPS)

- Publikasi di JOURNAL Internasional Bereputasi Indexed Scopus: ADVANCED SCIENCE LETTERS

- Pelaksanaan tanggal 26-27 July 2017

- Judul Article "Portable Urban Agriculture Technology and Soil Nutrient Drive App that support Farmers profit"

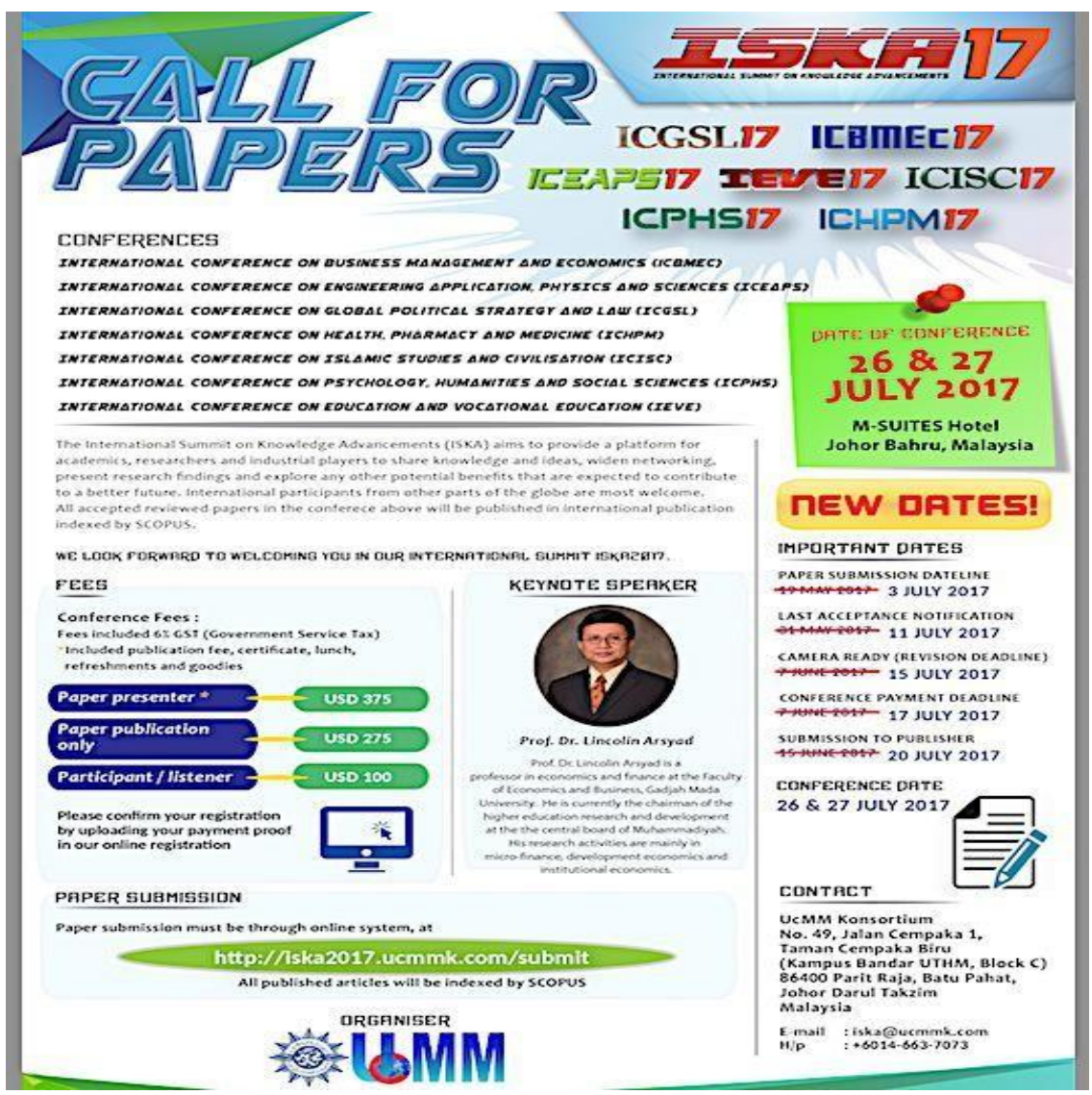




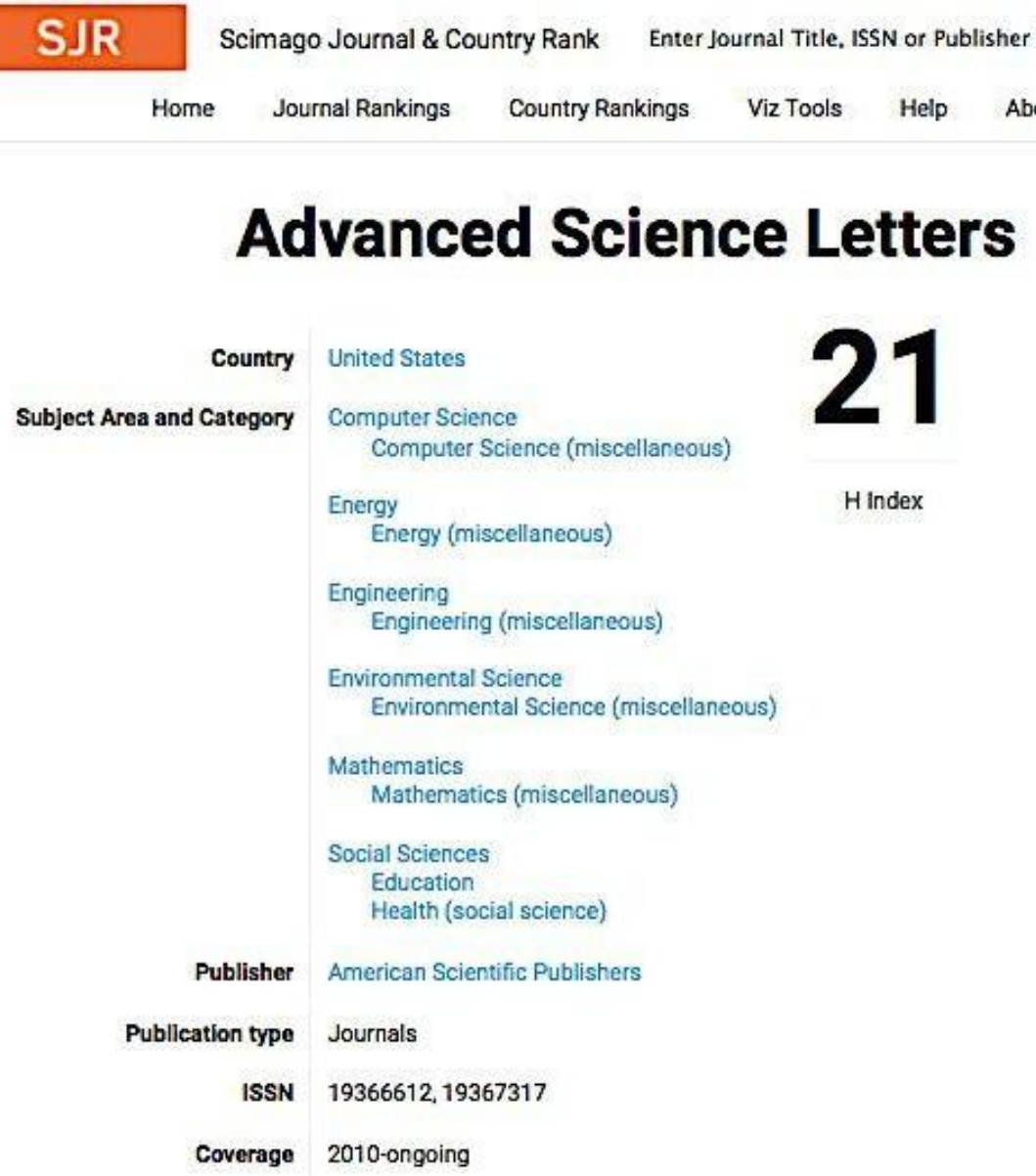

\section{Quartiles}

Computer Science (miscellaneous)

Education

Energy (miscellaneous)

Engineering (miscellaneous)

Environmental Science (miscellaneous)

Health (social science)

Mathematics (miscellaneous)

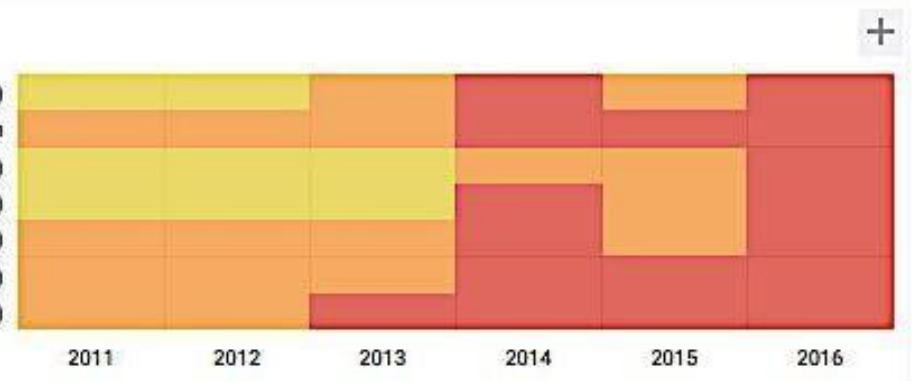




\section{Portable Urban Agriculture Technology and Soil Nutrient Drive App that support Farmers profit}

Ronny D Nasihien ${ }^{2}$, M. Ikhsan Setiawan', Diah Ayu Restuti Wulandari', Anton Muhibuddin ${ }^{2}$, Sugeng ${ }^{3}$, Wahyu Mulyo Utomo ${ }^{2}$ 'Narotarma University, Surabaya, 60117, Indonesia ${ }^{2}$ Brawijaya University, Malang, Indones

tUTHM, 86400 Parit Raja, Johot, Malaysia
cmail: ikhsan.setiawan@narotama.ac.id

Urban Agriculture was farmed by a narrow land. It used for daily fresh vegetables and fruit for the housing community in urban areas. Portable Urban Agriculture Technology as a support facility to increase production of Urban Agriculture, the Greenhouse portable system could be built and transferred to a specific location is convenient, safe, fast, lightweight structural material (PVC $0.55 \mathrm{~mm}$ Tarpaulin) so that the Urban A arricultural Products closer to residential consumers in urtan. The impact was the price was cheaper but quality. The objective was to plan, build and test prototype Water inflated tentactivity as a facility to strengthen Greenhouse's strength, speed, effectiveness and comfort. Application method stares of the Cup or SDN on a former tin mining land, with Portablo Urban A riculture Technolofy support soil nutrient drive are follows: (a) Roconstion of the land in the form of land as cxist in the field is very imports exist in the ficld is very imporant to support the sucesss or the soll development or VAM hyphae and ret system, (c) Sall Amendment to improve tho physical and chemical properties of former replanting of sustainable of native vegetation for erosion and runoff, repair and restoration of biodiversity, landscape aesthetics that will impact habitat improvernent fauna, biodiversity, soil productivity and water quality. Tree plant species such as Acacia mangium, Acacia auriculiformis and Leucacna diversifolia microbes that have becen infected with mycorrhizal fungi (VAM) will be very eftective and support this chor. Rovegelaton activies with SDN thethod includes the following steps: (a) Seedling plants with VAM; (b) Preparation of arable land that supports the development of VAM in the soil; (c) Planting of the first cup (1) with VAM; (d) Incubate 1 month; (e) Planting of the second cup (2) with VAM; (f) 1 month incubation; $(g)$ The planting of the main crop

Keywords: Portable Technology, Urban Agriculture, Agriculture Tourism, Greenhouse
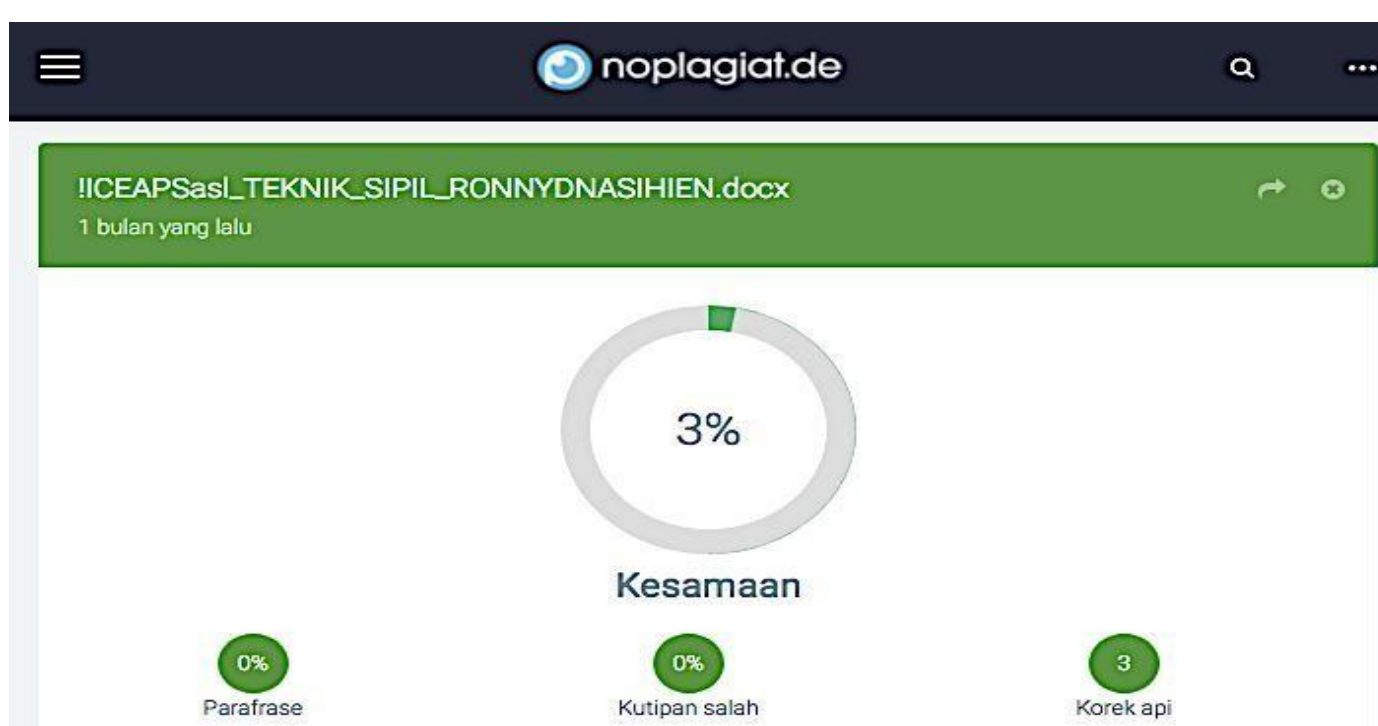


\section{Presenter Dan Publikasi Internasional (Google}

\section{Schoolar Indexed)}

- International Conference 14TH ADRI

INTERNATIONAL CONFERECEN and

CALL FOR PAPERS di Bali, Indonesia

- Publikasi di PROCEEDINGS Indexed Google Schoolar

- Pelaksanaan tanggal 11-12 Agustus 2017

- Judul Article "Urban Agriculture and

Vesicular Arbuscular Mycorrhizal provides

optimal results with Portable Greenhouse

Technology"
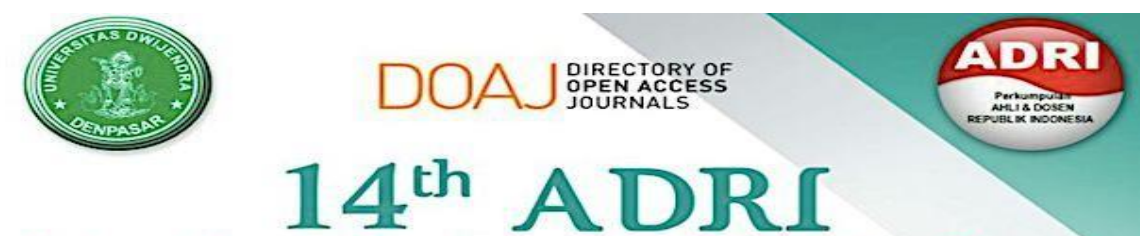

International Conference And Call for Papers

Theme

Development of Science through Strengthening the

Publication in Indexed Journals

$$
\text { Sub Themes }
$$

Formal Science, Natural Science, Humaniora, Applied Science,

Religious Studies, and Social Science

Keynote Speakers

1. Minister of Cooperatives and Small and Medium Enterprises,

Rol : Drs. A.A.N. G. Puspayoga

2. DG of Research and Development, Ministry of Research and Technology and Higher Education, Rol : Dr. M. Dimyati

3. Chairman of Dwijendra Foundation,

Rol : Dr.Drs. M.S. Chandra Jaya, M.Hum

International Speakers

Prof. Laurence Tamatea, Charles Darwin University (Australia)

2.Prof. Takahiro Osawa, Yarnaguchi University (Japan)

3.Dr. Peter Sprang. IRRI (Los Banos, the Philippines)

4.Judith Barnsby, Managing Editor DOAJ (United Kingdom

5. Tom Olijhoek, Editor in Chief DOAJ (Netherlands)

Dates

6.Leena Shah, DOAJ Ambassadors (India) 7.Hai Dal, (USA)

2. DOAJ Ambassador Training
2. Campus international Collaboration (CIC)
3. IC ADRI

Alegust 7-10., 2017
August 11,2017

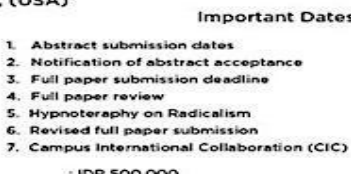




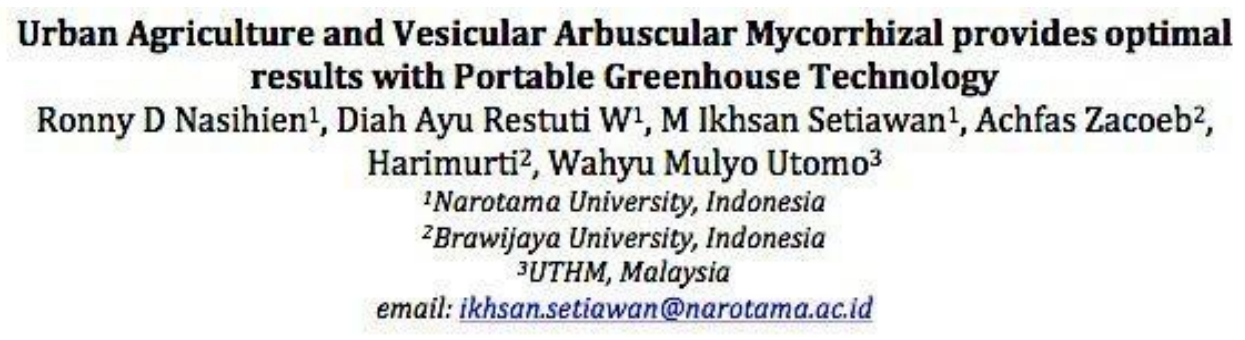

\begin{abstract}
Vesicular Arbuscular Mycorrhizal (VAM) is a fungus that penetrates the roots of a vascular plant in order to help them to capture nutrients from the soil. These fungi are scientifically well known for their ability to uptake and transport mineral nutrients from the soil directly into host plant roots. Approximately $80 \%$ of known plant species, including most economically important crops, have a known symbiosis with them. This mutually beneficial partnership between plants and soil fungi has existed as long as there have been plants growing in soil. Unfortunately, these beneficial mycorrhizal fungi are destroyed in the development of human-made landscapes, causing vegetation in these environments to struggle. When reintroduced to the soil, the mycorrhiza colonizes the root system, forming a vast network of filaments. This fungal system retains moisture while producing powerful enzymes that naturally unlock mineral nutrients in the soil for natural root absorption. Specific VAM symbiotic with plants also very profitable for farmers because it provides economic benefits in the form of chemical and non-chemical fertilizer reduction and pesticides. The hyphae network system that is formed will increase the ability of the root to absorb soil nutrients up to tens and even thousands of times. This ability will decrease the nutritional needs of plants from fertilizers and pesticides. Urban agriculture provides optimal results with facilities Greenhouse and Vesicular Arbuscular Mycorrhizal technology. Greenhouse improve crop protection from rainfall, sunshine and microclimate, as well as optimising plant maintenance, fertilisation and micro irrigation, so as to increase the production of vegetables, fruits and flowers of quality irrespective of the season. Greenhouse easier with technology Air inflated Structure that can qualify strength, comfort in the room and speed in Greenhouse build-up. membrane material can be resistant to weather up to more than 10 years, depending on the type of coating material
\end{abstract}

keywords: Vesicular Arbuscular Mycorrhizal, Urban agriculture, Greenhouse 


\section{Kesimpulan Dan Saran}

1. Pada tahun pertama (2017) telah dilakukan Uji LAB Prototipe Portable Inflated Greenhouse Tanaman Buah/Sayur dengan teknologi VAM, melalui kegiatan: (a) Uji Coba di LAB Universitas Narotama, meliputi: (1) Uji fleksibilitas, kecepatan, efektifitas produk Prototipe Portable Inflated Greenhouse; (2) Uji daya tahan tanaman buah/sayuran dengan teknologi VAM dalam Prototipe; (b) Uji Coba Daya Tahan Tanaman Buah/Sayur dengan teknologi VAM. Kemudian dilanjutkan dengan Metode dan Teknik Analisis berupa analisis Kuantitatif (menggunakan Termometer, Stopwatch). Hasil akhir diperoleh Produk Prototipe Portable Inflated Greenhouse dengan Tanaman Buah/Sayur dengan teknologi VAM, yang telah di Uji Coba di LAB dan telah dilakukan revisi produk atas hasil Uji Coba di LAB Universitas Narotama tersebut, berdasarkan masukan Tim Peneliti Mitra dari Universitas Brawijaya (Malang, Indonesia)

2. Berdasarkan analisis kelayakan tersebut, telah dihasilkan produk ilmiah meliputi:
a. Pemakalah dalam temu ilmiah internasional
b. Publikasi ilmiah internasional
c. Proses Hak kekayaan intelektual HKI berupa PATEN
d. Proses Buku Ajar ISBN
e. Tingkat kesiapan teknologi TKT, LEVEL 4 DEFINISI/STATUS:

Komponen teknologi telah divalidasi dalam lingkungan laboratorium INDIKATOR:

a. Test laboratorium komponen-komponen secara terpisah telah dilakukan;

b. Kinerja dari masing-masing komponen teknologi (cara/metode/proses/produk) yang akan dikembangkan telah menunjukan hasil yang baik;

c. Percobaan fungsi utama teknologi dalam lingkungan yang relevan telah dilaksanakan; 
d. Prototipe teknologi skala laboratorium telah dibuat;

e. Penelitian integrasi komponen telah dimulai;

f. Analisis awal menunjukkan bahwa fungsi utama yang dibutuhkan dapat bekerja dengan baik.

g. Integrasi komponen teknologi dan rancang bangunskala laboratorium telah diuji (low fidelity)..

\section{Saran}

Perlunya penambahan durasi lebih lama untuk penyelesaian PATEN Hak Cipta, disebabkan melibatkan lintas Kementerian, tidak hanya Kementerian RISTEKDIKTI tetapi juga Dirjen HAKI Kementerian KUMHAM

\section{Daftar Pustaka}

Budiyanto, Hery. 1992. Kajian dan Perancangan Bangunan dengan Konsep Struktur Pneumatik yang Ditekankan pada Aspek Teknik dan Metoda Konstruksi, Kasus Studi: Struktur Atap Pneumatik Membran Tunggal yang Ditumpu Udara pada Gedung Olah Raga, Tesis S2. Bandung: Institut Teknologi Bandung

Budiyanto, Hery. 2007. Ujicoba Model Dan Prototipe Tenda Pneumatik Sistem Knock Down Sebagai Bangunan Penampungan Sementara Untuk Korban Bencana. Laporan Penelitian Hibah Kompetisi A2, Teknik Arsitektur Universitas Narotama.

Budiyanto, Hery. 2010. Pembuatan Tenda Pneumatik Sistem Knock Down Yang Ringkas Dan Cepat Bangun Sebagai Bangunan Penampungan Sementara Untuk Korban Bencana. Laporan Penelitian Hibah Bersaing Tahun 2008-2010. Teknik Arsitektur Universitas Narotama.

Butler, L, Moronek, D.M. 2002. Urban and Agriculture Communities: Opportunities for Common Ground, Ames, Iowa: Council for Agricultural Science and Technology.

Chassagnoux, Alain, et.al. 2002. Teaching of Morphology, International Journal of Space Structures, Vol.17 No. 2 \& 3. Multi Science Publishing Ltd., Brendwood (UK).

Delta Institute. Urban Agriculture

Dent, Roger N. 1971. Principles of Pneumatic Architecture. London: Elsevier Publishing Company.

Fraser, Evan, D.G. 2002. Urban Ecology in Bangkok Thailand: Community Participation, Urban Agriculture and Forestry, Environments 30 (1).

G. Thiyagarajan, R. Umadevi \& K. Ramesh. 2007. Hydroponics. India: Science Tech Entrepreneur-Water Technology Centre-Tamil Nadu Agricultural University.

Ghana, Ayu Kemala. 2014. Peranan Urban Farming dalam Menarik Minat Beli 
Konsumen pada Real Estate Perumahan di Surabaya. Tesis. S2 Arsitektur - Perancangan Real Estate. Surabaya: ITS.

Herzog, Thomas. 1976. Pneumatic Structures, a Handbook for the Architect and Engineer. London: Crosby Lockwood Staples.

Intent. 2005. Membran Structures. Kortrijk: Intent Inc.

Itek. 2005. Air Cell Technology. Pennsylvania: Inflatable Technology-USA Inc.

Luchsinger, Rolf H. et.al. 2004. Pressure Indicated Stability: From Pneumatic

Structure to Tensairity. Article No.JBE-2004-025. Journal of Bionic

Engineering. Vol.1. No.3, hal.141-148, Cina: Jilin University - Nanling Campus, Changchun PR China.

Otto, Frei.1973. Tensile Structures. Cambridge: The MIT Press.

Purwanto. 2000. Perkembangan Struktur Pneumatik Memperkaya Desain Arsitektur. Jurnal Dimensi Vol 28 No. 1, Surabaya: Universitas Kristen Petra.

Salvadori, Mario. 1981. Structural Design in Architecture. New Jersey: Prentice Hall Inc.

Schodek, Daniel. 1980. Structures. New Jersey: Prentice Hall. Inc.

Schueller, Wolfgang. 1983. Horizontal Span Building Structures. New York: John Wiley \& Sons.

Setiawan, M. Ikhsan, Nasihien, Ronny D, et.al. 2014. The Development of Portable inflated Structure as the Facility on Natural Disaster Area. Australian: Journal of Basic and Applied Sciences, ISSN 1991-8178, April Issue 2014.

Setiawan, M. Ikhsan, Nasihien, Ronny D, et.al. 2015. Pengembangan Bangunan Portable inflated Structure sebagai fasilitas Tanggap Bencana, Seminar Nasional Teknologi (SENATEK). Malang: ITN.

Setiawan, M. Ikhsan, Nasihien, Ronny D, et.al. 2015. Poros Maritim Dunia dan Bencana Tsunami: Pengembangan Portable inflated Structure sebagai fasilitas Tanggap Bencana. Surabaya: Seminar Nasional Teknik Sipil XI2015, ITS Surabaya.

Smit, J., A. Ratta, J. Nasr. 1996. Urban Agriculture: Food, Jobs, and Sustainable Cities. United Nations Development Programme (UNDP). New York: NY.

Sukawi. 2011. Struktur Membran dalam Bangunan Bentang Lebar. Jurnal Modul Vol.11 No.1. ISSN:0853-2877. Semarang: Universitas Diponegoro.

Thornton. 2011. Food for thought? The Potential of Urban Agriculture in Local Food Production for Food Security in the South Pacific. In Campbell, H. Rosin, C. and Stock, P. (eds) Dimensions of the Global Food Crisis. London: Earthscan. Pg 200-218.

www.industri.bisnis.com www.kabarkampus.com www.trubus-online.co.id

Xuereb, Marc. 2005. Food Miles: Environmental Implications of Food Imports to Waterloo Region. Public Health Planner Region of Waterloo Public Health

Zuhri, Syaifudin. 2010. Dasar-dasar Tektonik: Arsitektur dan Struktur. Klaten: Yayasan Humaniora. 